\title{
Rhetorically decentralised, practically recentralised: a review of the local governance system of Ghana
}

\author{
David Anaafo \\ Department of Environmental Management \\ University of Energy and Natural Resources \\ PO Box 214 Sunyani \\ Ghana \\ Email: david.anaafo@uenr.edu.gh
}

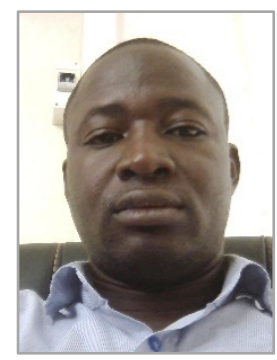

\begin{abstract}
There is currently a global quest to decentralise government functions, which has resonated well with many developing countries. Ghana has over the last few decades embraced decentralisation in principle, as a way of promoting inclusive, efficient, accountable and bottom-up local-level governance. However, it is unclear how successfully this vision is being achieved. Using a heuristic continuum as an analytical framework, this study conducted a literature- and statute-based politico-administrative review of the local governance system of Ghana to ascertain the extent of decentralisation. The study concludes that the legislative, political and administrative arrangements in place make it easy for the centre to usurp the powers of local authorities.
\end{abstract}

Keywords: Ghana, decentralisation, recentralisation, politico-administrative

\section{Introduction}

Decentralisation as a tool for devolving power from the centre to the periphery has gained traction across the global south over the last few decades (Manor 1999; European Commission 2007; Lambright 2011; McLaverty 2017). While there are varying degrees of commitment and success, the main drivers of this growing recourse to decentralisation in the developing world are generally agreed to be: the growing need to apply participatory development approaches; the need for efficient delivery of basic social services; and the collapse of the centralised state of the 1980s (Boex and Yilmaz 2010; Diamond 1999; Eaton et al. 2011; European Commission 2007; Ouedraogo 2003).

Ghana is one of the developing countries that has taken to decentralisation as a way of promoting inclusive, efficient, accountable and bottom-up local-level governance. The 1992 Constitution of the 
Republic of Ghana, the (now superseded) Local Government Act 1993 and its successor the Local Governance Act 2016, together with a variety of other legislation, provide the basis for Ghana's quest to establish a functional local and national governance framework (Ewool 2003; Crawford 2004). Since the inception of the district assembly concept (a system of local governance that seeks to involve stakeholders in decisions on issues that affect them), Ghanaians have embraced metropolitan, municipal and district assemblies (MMDAs) as the local institutions mandated to address their socio-economic and other developmental needs.

The process of decentralisation is not devoid of challenges, however, as political, institutional and general administrative practices exhibit strong tendencies towards recentralisation in many African countries. Over 15 years ago Wunsch (2001) observed that decentralisation reforms in many African countries were stagnating because of the inability of governments to translate reform initiatives into implementation at the local level. He argued that reforms involving planning and capital investment, budgeting and fiscal management, personnel systems and management, and finance and revenue, had stalled due to reluctance on the part of central government actors to relinquish power, and/or the complexity of effective organisational redesign. He concluded that power transferred to local governments was most often recaptured by the centre due to loopholes, deliberately inserted in the decentralisation legislation. These loopholes included: provisions requiring ministry sign-off on budgets and annual plans; poorly trained local staff resulting in poor functioning of local authorities; poorly designed local institutions, militating against effective local decision-making; and the absence of an effective local political process to engender participation and accountability in the local governance process (Eaton et al. 20011; Wunsch 2001). As a remedy, Wunsch suggested cautiously crafted legislation that embraces good practice - although stressing that this could lead to some further reassertion of central control over local authorities (Eaton et al. 2011).

Ghana's decentralisation efforts seem to fit well into this analytical framework. An Afrobarometer (2008) briefing paper on popular opinions on local governance in Ghana found that only $43 \%$ of Ghanaians realise that local government authorities are responsible for the statutory tasks specifically assigned to them. The other $57 \%$ believe that central government is responsible - including for services as basic as operating a health clinic. The report concludes: "It appears that popular understandings of local government functions remain steeped in Ghana's traditions of centralized public administration" (Afrobarometer 2008, p. 3). This misconception is understandable, since a number of practices affecting local government suggest the reassertion of central control over local authorities. Examples are the continued appointment of district chief executives (DCEs) by the president, as opposed to their election; the appointment of $30 \%$ of local legislators by the president; issues with recruitment, placement and personnel management; constraints on revenue mobilisation and fiscal autonomy; and controls over development planning and implementation. Ayee (2008) has argued that, although Ghana has a comprehensive local government policy that dates back to 1988 , in practice the country still runs as a 
highly centralised top-down public administrative political system. He even concludes that, where decentralisation is pursued, this is not as a tool for devolving power and improving socio-economic development, but rather as a means of realising "political objectives such as the recentralisation of power and legitimacy" (Ayee 2008, p. 243).

\section{Objectives and structure of the paper}

This paper therefore explores the decentralisation system of Ghana to ascertain whether it is gaining strength, stalling or recentralising, by reviewing a number of legislative and administrative arrangements underpinning local governance in Ghana. Given Ghana's professed desire and enthusiasm to decentralise, however, any outcome of the analysis other than a relatively highly decentralised system will suggest recentralisation, as it will mean that all the reforms undertaken over the years are not achieving their goals. Following the introduction, the paper explains the study's methodology and analytical framework. It then provides an overview of the decentralisation journey of Ghana, beginning from 1988, followed by a theoretical discussion of the concepts of centralisation, decentralisation and recentralisation. The analytical framework is then used to examine the state of decentralisation in Ghana, with this discussion followed by concluding comments.

\section{Study methods and analytical framework}

This study is a politico-administrative review of the decentralisation trajectory of Ghana. The term 'politico-administrative' is used here to refer to the nexus between policy formulation and on-theground implementation mechanisms. The analysis is limited to the progress and state of decentralisation under Ghana's Fourth Republic, which came into existence with the promulgation of the 1992 Republican Constitution. However, as the decentralisation drive started in 1988, four clear years before the return to constitutional democracy in 1992, occasional references are made to developments during that period. The study reviews policy documents, decentralisation reform initiatives, relevant legislation and on-the-ground practices, involving appointments, recruitment, placement and management of local government personnel to examine whether Ghana is making strides in its decentralisation drive - or otherwise.

Analytically, the study uses the heuristic continuum developed by Hutchcroft (2001) based on his analysis of scholarly works on state formation and public administration. This continuum places full centralisation and full decentralisation at opposite extremes, although it is argued that neither of these 'pure' forms exist in the real world. However, it is possible to determine whether the governance system of a country is relatively more centralised or relatively more decentralised. 
Hutchcroft argues that a highly centralised political system will have an extensive combination of the following:

1) local and regional officials are appointed by the centre; 2) there are few avenues for political participation at the local level; 3) subnational units lack their legislative bodies; 4) there are no local bosses to challenge the authority of the centre; 5) decision-making authority at the capital is concentrated in the executive (or, if there is a national legislature, it has little real say); 6) the legislature (presuming it exists) has been established as part of a parliamentary structure, not a presidential one; 7) a significant proportion of national legislators are appointed by the centre; 8) there is a proportional representation electoral system (and selection of candidates within this system is determined by a national political party); 9) all political parties are national in scope, and capable of enforcing national-level decisions/strategies throughout the country; 10) bureaucracies are well insulated from systems of patronage (2001, p. 37).

He similarly argues that opposite characteristics will be true in a highly decentralised system.

Alternatively, Boex and Yilmaz (2010) have proposed six variables for assessing the state of decentralisation of governments, which are based on the technical and administrative dimensions of governance. Their framework identifies these variables as: political empowerment and decentralisation; administrative empowerment and decentralisation; fiscal empowerment and decentralisation; central government policy, legislation and institutions; local government institutions, management and administration; and civil society and the private sector. Eaton et al. (2011) have also proposed a range of (four) major variables regarding national and intergovernmental relations as an appropriate framework for the assessment of the effectiveness of different types of local government system. These include: the context and motivations underpinning decentralisation; the stakeholders involved in the decentralisation processes; the stage of reform vis-à-vis the baseline situation; and the roles and motivations of external development partners.

As these propositions do not differ significantly from Hutchcroft's (2001) framework, this study has chosen to use Hutchcroft's analytical framework to examine the local governance system of Ghana. The framework (see Figure 1) shows that it is possible for a country to transition from a highly centralised system of governance to a highly decentralised one - and vice versa. However, most countries operate more gradually, seeking to either decentralise or centralise government functions. 


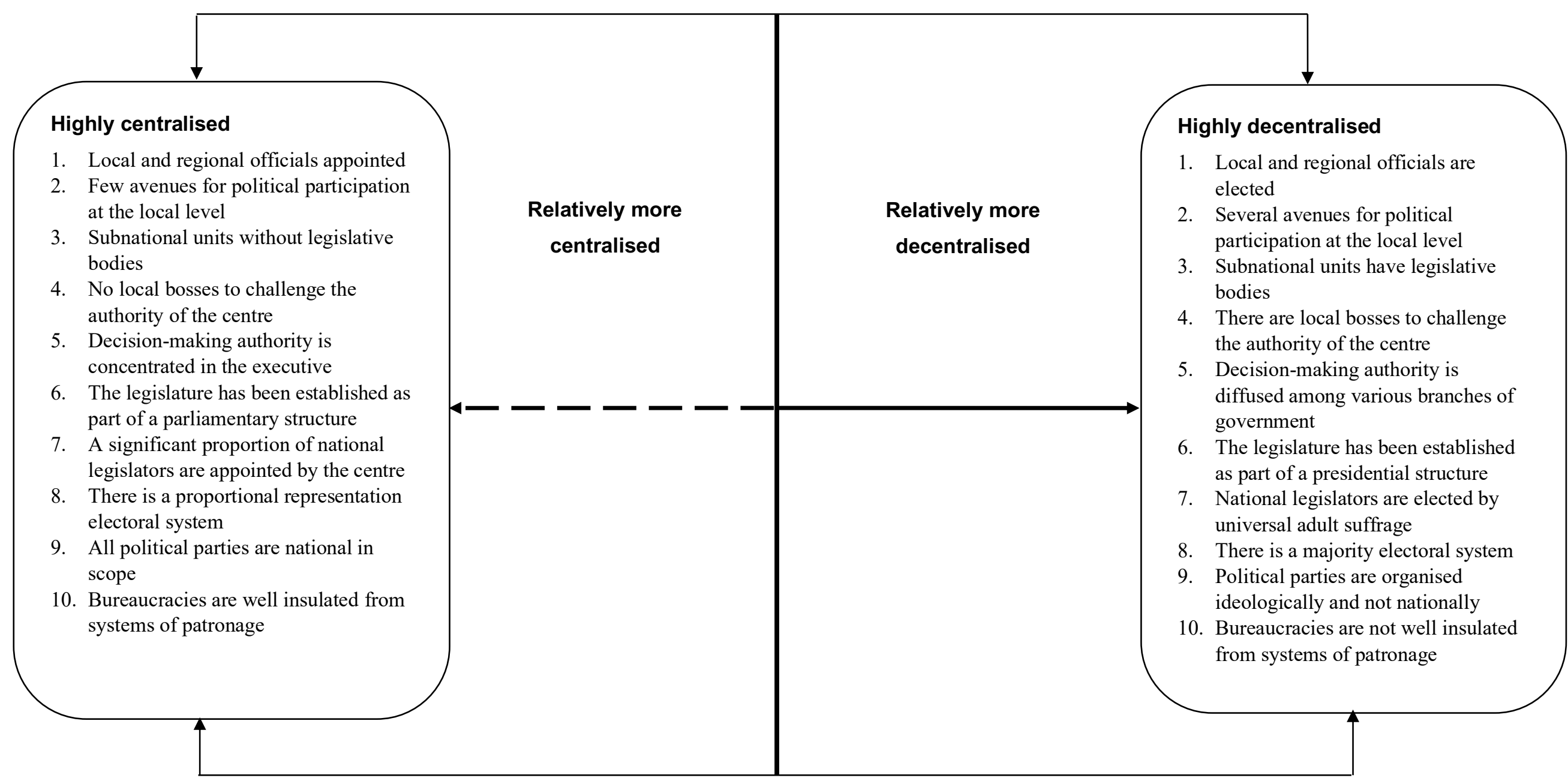

Figure 1: Centralisation/decentralisation continuum

Source: author's construct 2017

\section{Key}

४----- Relatively more centralised

Relatively more decentralised 
This study, however, makes use of only the first five and the tenth variables (six in all) in the framework for the analysis of the Ghanaian system. Variable 6 is not used because Ghana operates a quasiexecutive presidential system of governance and a constitution modelled on that of the United States of America, which seeks to ensure strict separation of powers. As such the legislature is not part of a parliamentary structure. Variable 7 is not used because all legislators gain entry to the parliament of Ghana through elections, as opposed to appointments. Variable 8 is not used because Ghana is a unitary country with a presidential system of governance. Finally, variable 9 is discarded because, although Ghanaian political parties are national in character, the aim, as captured in Article 55 Section 4 of the 1992 Constitution of the Republic of Ghana is to enhance national unity and cohesion as opposed to enabling parties to enforce decisions nationwide. Consequently, these four variables are not used, because their likelihood of significantly affecting centre-periphery relationships is very minimal, if not entirely negligible.

\section{The local governance system of Ghana}

Although decentralised local governance in Ghana can be traced back as far as 1878 (Ayee 2000; DickSagoe 2012), the current system began in 1988, with the introduction of the Local Government Law Provisional National Defence Council Law (PNDCL) 207, (Crawford 2004). Initial attempts at decentralisation in Ghana occurred under the colonial regime, with the establishment of 355 native authorities, whose powers revolved around a chief or some local royalty. The native authorities existed basically to help British colonisers in the administration of the country, and their involvement in local government was limited. Subsequently, various legal instruments - the Municipal Ordinance of 1859; another ordinance establishing elected town councils for Accra, Kumasi, Sekondi-Takoradi and Cape Coast in 1943; the Municipal Councils Ordinance of 1953; and the Local Government Act (Act 54 of 1961) - supported decentralised governance during the colonial and immediate post-colonial eras (Ayee 2008). The thrust of decentralisation policy in Ghana as it exists today, however, has been to transfer power, authority, functions, competence and resources from the centre to the periphery, as a way of promoting popular participation and consultation in local governance processes (Ahwoi, 2010).

The implementation of PNDCL 207 led to an initial increase in the number of districts from 65 to 110 (and later to 216) within the country's ten politico-administrative regions. The decentralisation drive then received constitutional legitimacy in 1992 with the promulgation of the 1992 Constitution, which mandated successive governments to ensure that Ghana remained a truly decentralised country. This approach was consolidated by various subsequent Acts, including: the Local Government Act 1993 (Act 462); the District Assemblies' Common Fund Act 1993 (Act 455); the Civil Service Law 1993; PNDCL 327; the National Development Planning (Systems) Act 1994 (Act 480); the Local Government Service Act 2003, (Act 656); the Institute of Local Government Studies Act 2003, (Act 647); and the Local Governance Act 2016 (Act 936) (Ahwoi 2010; Goel 2010; Dick-Sagoe 2012). 
In principle, the decentralisation system of Ghana is characterised by the following: re-demarcation of various districts into smaller and more manageable local government units; non-partisan local government bodies; district assemblies mandated to perform legislative, administrative, development planning, service delivery, budgeting and rating functions; removal of obstacles to grassroots participation in the local governance processes; $30 \%$ of district assembly members appointed by the president in consultation with traditional rulers; a system of decentralised planning; and resource- and revenue-sharing between central and local governments (Government of Ghana 2016).

The country is divided into ten administrative regions, containing 216 MMDAs. These MMDAs are further sub-divided into 1,306 urban, zonal, town and area councils and 16,000 unit committees. Each of the ten regions is headed by a regional minister, appointed by the president and endorsed by parliament. The MMDAs are headed by DCEs, again appointed by the president but subject to a twothirds majority approval vote among members of the district assembly - the highest decision-making body at the local level.

According to Chireh (2009), Ghana's decentralisation system is underpinned by the following pillars:

- devolution of central government functions and authority to subnational government bodies;

- fusion of decentralised governmental departments and agencies at the subnational level into an integrated administrative system;

- reorganisation and restructuring of responsibilities, with greater implementation responsibilities resting on local government units; and

- active participation of various segments of the local population in local decision-making and implementation processes.

If Chireh's description is correct, it implies that Ghana is making significant efforts to deepen local governance: through devolving functions, ensuring that MMDAs have oversight responsibility over all decentralised governmental bodies, and providing opportunities for participatory governance at the grassroots level. Practically, however, there are various impediments to these processes, which are the subject of this research.

\section{Defining centralisation, decentralisation and recentralisation}

Governance can be simply understood as the organisation of human activities in space and time. From a historical perspective, however, it can be argued that the sole purpose of this has often been to make communities and the people residing therein governable and/or manipulable (Scott 1998). Centralisation, decentralisation and recentralisation are concepts used by governments in different ways to organise nation states and make them governable. Centralisation is defined by Besley and Coate (2003) as a system of governance whereby decisions over government expenditure are centrally made 
and financed from general revenues. It has long been argued that the modern state is an embodiment of administrative centralisation because "political relations radiate to and from a center, to cover a ... territorially demarcated area over which it exercises ... some degree of authoritative, binding rule making, backed up by some organised physical force." (Mann 1993, p. 55). One way to achieve centralisation is through a system of prefectoralism: a governance system whereby the country is divided into various units, headed by prefects, who are expected to represent the central government, and who supervise all local-level actors (Hutchcroft 2001).

Within the African context, Wunsch and Olowu (1990) and Gennaioli and Rainer (2007) have argued that most African countries are centrally governed, with a resulting lack of accountability, poor supervision and inadequate participation by the ordinary people in the governance processes. They emphasise that this ruler/ruled relationship also stifles dissenting views, resulting in flawed policy processes and errors of judgement in the overall governance processes. Whether this assessment is true of Ghana is subject to debate.

Decentralisation, by contrast, can be defined as "any act in which a central government formally cedes powers to actors and institutions at lower levels in a political-administrative and territorial hierarchy" (Ribot 2001, p. v). Three main forms of decentralisation are identified in the literature. According to Manor (1999) they are 1) deconcentration or administrative decentralisation, 2) fiscal decentralisation, and 3) political decentralisation, also sometimes termed democratic decentralisation or devolution. It is further suggested (Manor, 1999) that while it is possible for each of these forms of decentralisation to exist in isolation, it is equally possible to have a combination, or all three working together, within a given system. In deconcentration or administrative decentralisation, local branches of central government bodies are created to perform assigned tasks, but local officials remain accountable to their respective central ministries. Fiscal decentralisation, by contrast, entails the transfer of fiscal resources, revenue-generating powers and authority over budgets to local-level officials (who may be elected or appointed). Finally, devolution, the third and most complete form of decentralisation, entails the transfer of functions, powers and resources to independent and democratically elected subnational bodies (Manor 1999; Crawford 2004). This paper is particularly concerned with administrative decentralisation/deconcentration and political/democratic decentralisation/devolution, although occasional references are made to fiscal decentralisation.

Recentralisation has not been succinctly defined in the literature. In this study, however, it is perceived as a process whereby supposedly decentralised governmental structures are, covertly and/or overtly, recaptured by the centre through processes such as central government directives and administrative fiats. It is a process which deprives local-level actors of any initiative, by ensuring that they serve the interest of the centre as opposed to that of the local area. The result is that central government retains 
control over local affairs by appointing government functionaries, requisitioning fiscal resources and controlling the staff base of local government bodies.

\section{Current state of decentralisation in Ghana}

Ghana's laws seek to establish a system of local governance. The key objectives of decentralisation, as contained in the 1992 Constitution of Ghana are: democratic participatory governance; effective and efficient service delivery; and rapid socio-economic development. These objectives were to be achieved through a combination of mechanisms: a political process of creating regional coordinating councils (RCCs), MMDAs and sub-district structures; an administrative process of transferring staff from central government ministries to local governments; fiscal decentralisation; decentralised planning, whereby MMDAs become planning authorities; and the decentralised management of public-private partnerships.

Some 25 years after the Constitution's promulgation, it has become imperative to examine the extent to which the country is making progress - or otherwise - on the decentralisation journey. This paper therefore now discusses Ghana's current position, taking in turn the six relevant variables of Hutchcroft (2001).

\section{To what extent are local and regional officials appointed or elected?}

Of particular interest to this research is the method by which ministers and DCEs obtain their positions. Regional ministers are appointed by the president and approved by parliament. The effect of this is that their loyalty is first and foremost to the president, who has the power to replace them without explanation. DCEs, on the other hand, although also appointed by the president, must be approved by a two-thirds majority of the members forming their district assembly (the local legislature), present and voting. Interestingly, however, $30 \%$ of these members are also appointed by the president, which some critics assert is to ensure that his nominees attain the minimum votes required for their confirmation as DCEs. Despite some criticism, this provision was retained in the Local Governance Act 2016. DCE appointments help central government realise its political objectives at the local level, as its representatives work based on orders and directives from the centre as opposed to focusing on local initiatives.

Beyond these two key officials, another important centralising influence is the fact that the staff of the various decentralised bodies are actually employees of central government. Their recruitment, posting, promotion, transfer and disciplining are determined by the local government service secretariat, a central government level public institution with the mandate to secure effective administration and management of the decentralised local government system in the country. The local government service secretariat is a creation of the Local Government Service Act 2003, whose head is, again, a presidential appointee. Basic functions such as organisational and job analysis, management audits, personnel needs 
assessment and the development of personnel plans, professional standards and guidelines for different categories of staff - which should ordinarily be performed by MMDAs - are instead performed by the secretariat, a clear usurpation of the powers of MMDAs.

Again, the governing body of the local government service is made up entirely of central government functionaries, namely a representative from each of the ministries responsible for local government, education, and health, all of whom should not be below the rank of a director. Other members include: the director general of the National Development Planning Commission (NDPC) or his/her representative; the head of the local government service; the administrator of the District Assemblies' Common Fund or his/her representative; a representative of the local government workers, nominated by the workers; the director of the Institute of Local Government Studies or his/her representative; a representative of the National House of Chiefs; two representatives of civil society organisations with considerable knowledge of local government and decentralisation matters, nominated by the minister of local government; and two women with considerable knowledge of local government and decentralisation matters, also nominated by the minister. This means that the entire membership of the local government service governing council, is appointed by the president (Government of Ghana 2016).

This current system is, however, at variance with that envisaged by most Ghanaians. A report by the African Peer Review Mechanism (2005) established, for instance, that most Ghanaians would prefer to have elected as opposed to appointed DCEs. This claim was corroborated quite recently by the government's own Constitution Review Commission, which established that an overwhelming majority of Ghanaians favoured a system of local government whereby DCEs are elected rather than appointed (Government of Ghana 2012).

However, successive governments have preferred to appoint rather than elect DCEs because it gives them some hold over local affairs. Beyond the appointment of DCEs and regional ministers, other provisions such as the appointment of $30 \%$ of the members of district assemblies and national control over the audit of local governments further deprive MMDAs of initiative and autonomy. The authors of this paper argue, however, with many other academics, that a functional local government system would more appropriately be given a "clear mandate, architecture, functions, and considerable discretion over the use of its funds and implementation" of initiatives (Ferrazzi 2006, p. 4).

There is a clear tension in Ghana's structures. While the 1992 Constitution, the Local Government Act 1993, and the Local Governance Act 2016 all support the creation of autonomous local government bodies, governments have managed to subvert this process, mostly by relying on the muted language (e.g. phrases such as 'as far as practicable') in which various sections of the legislation are couched (Ferrazzi 2006). Crawford (2004, p. 18) also observes that the appointment of DCEs is inconsistent with 
democratic practices, because it encourages "upward accountability to central government rather than downward accountability to the local electorate".

\section{To what extent are there local avenues for participation in the local governance process?}

Constitutionally, Ghana's system of decentralisation does support popular participation in local governance. Article 240 (e) of the 1992 Constitution of Ghana states that "to ensure the accountability of local government authorities, people in particular local government areas shall, as far as practicable, be afforded the opportunity to participate effectively in their governance" (Republic of Ghana 1992, p. 139). Section 40 of the Local Governance Act 2016 also mandates MMDAs to create appropriate avenues for residents and other stakeholders to effectively participate in their affairs. They are expected to achieve this using ICT, town hall meetings, budget preparation and validation meetings; announcements on noticeboards; and site visits. It must, however, be noted that participation is a broad concept which can take various forms. These have been summarised to include information-sharing, consultation, service access, input to programmes, election, representation, association and collaboration (Institute of Local Government Studies and Friedrich Ebert Stiftung 2010).

In seeking to actualise the legal requirements, a number of rounds of local government elections have been held since 1988: in 1988/89, 1994, 1998, 2002, 2006 (Agomor and Obayashi 2008), 2010 and 2015. However, voter turnout has been very low compared to presidential elections. For example, turnout in the 2002 local government elections was $32.8 \%$, while turnout for the 2004 presidential and parliamentary elections was $81.5 \%$ (Ayee 2008). It may be that turnout in local-level elections remains low because of the relatively weak nature of local governments in Ghana and lingering doubts about the impact of electorate votes on the performance of the system. It is plausible to argue that voters show little interest in local government elections because they are not genuine electoral contests, and because the most powerful positions remain appointive.

The issue of participation in local government in Ghana is also highlighted in the area of development planning. The National Development Planning (Systems) Act 1994 (Act 480) governs decentralised planning in Ghana. This is structured to comprise district planning authorities, RCCs, and sector agencies, departments and ministries - at the local, regional and national levels respectively - with the NDPC playing a supervisory role (Ayee 2008; Cobbinah and Korah 2016). It is further suggested (Ayee 2008) that important features of the decentralised planning system include the requirement of public hearings for district, sub-district and local development plans; the preparation of sub-district plans and the definition of planning areas; and the creation of joint planning areas and special development areas. Despite these provisions, however, Boamah et al. (2012) and Nunbogu (2014) report that planning in Ghana is still highly centralised and nationally oriented and does not provide adequate opportunities for community development and engagement. There is also a general lack of interest by the public in 
planning processes, and the requirement for public hearings is not adhered to by local authorities. In instances where hearings have been held at all, there has been little debate on the issues (Ayee 2008). Participation of civil society organisations in local governance processes has not been any better.

Alongside the seeming lack of interest in public hearings by local governments, another problem is how they are conducted. They are susceptible to control and micro-management from the NDPC at the centre, since Section 88, sub-section 5 of the Local Governance Act 2016 stipulates that "the Commission may, by legislative instrument, prescribe the manner in which the public hearing shall be conducted". The broad wording of this power means that the participatory processes contained in various legislative and policy documents are equally subject to capture by the centre.

Again, while local plans do need to be approved by local legislators, the 2016 Act endorses earlier laws by vesting powers of approval in the NDPC. It is the responsibility of the NDPC, under Section 86, subsection 3 (a) and (b) of the Act, to "determine the compatibility of district development plans with national development objectives" and where approved incorporate such plans into the national development plan. Sub-section 4 enjoins MMDAs not to alter approved district development plans without the prior approval of the NDPC. This implies that, although MMDAs are nominally planning authorities, their authority is recognisable only to the extent that their actions conform to the dictates of the NDPC.

\section{How independent are local legislatures?}

Politically, the main power-brokers at the district level are the DCEs, the local member(s) of parliament (MP), the presiding member of the local legislature and the district assembly members (elected and appointed). These various actors wield executive, legislative and deliberative powers. Article 241 (3) of the Constitution states that "subject to this Constitution, a District Assembly shall be the highest political authority in the district, and shall have deliberative, legislative and executive powers", (Republic of Ghana 1992, p. 140).

As discussed above, the DCE is appointed by the president and approved by two-thirds of the district assembly members present and voting. The DCE wields political, executive and administrative powers, and in many functions represents central government in the district: presiding over executive committee and tender committee meetings; supervising decentralised departments of the district assembly; and leading the administrative and executive functions of the district assembly (Institute of Local Government Studies and Friedrich Ebert Stiftung 2010; Government of Ghana 2016).

The local legislature is presided over by a presiding member, who must be a district assembly member, but who is voted in by other assembly members and must obtain two-thirds of the votes cast. Presiding members are elected for a period of two years, and are eligible for re-election. Presiding members chair 
and run general assembly meetings, have voting rights, chair the statutory public relations and complaints committee and also chair credit approval committee meetings (Government of Ghana 2016).

MPs represent the constituency and/or constituencies which are coterminous with their district in the national legislature. They are elected through universal adult suffrage from multi-party lists. They usually serve for a period of four years and may stand for re-election. MPs' functions include guiding the general assembly on new legislation; identifying local problems and advocating for their resolution in parliament; briefing the local assembly about proceedings of the national legislature; and providing feedback to their electorate on programmes/projects being implemented (Institute of Local Government and Friedrich Ebert Stiftung 2010).

Assembly members are at the centre of the decentralisation process of Ghana. They are the link between the district assembly and the various communities or electoral areas that make up the district. They are elected or appointed for a term of four years, and are eligible for re-election/appointment. Assembly members are expected to participate actively in committee meetings of the assembly; disseminate government policies and programmes to the electorate; consult the electorate on major policy issues; and articulate the views, concerns and interests of their electorate at assembly meetings (Government of Ghana 2016).

Of interest to this research is the extent to which the local legislatures (district assemblies) are independent of central government manipulation and directives. It is suggested that the constitutional provisions which empower the president to appoint both district chief executives and $30 \%$ of district assembly members are a sure-fire recipe for central government interference in, and control of local legislatures. These arrangements enable central government to push its agenda on local legislatures through subtle manoeuvring by the appointed district chief executives and assembly members. Ferrazzi (2006) even argues that by these arrangements the Constitution conceptualises the functions of local governments as emanating from central government - as opposed to from the local governments as the case should be.

Crawford (2004) chastises the local system of Ghana, arguing that the retention of presidential appointments and non-party-political local elections compromise essential democratic elements. He points out that the district assembly committee system is so organised that all sub-committees report to the assembly through the executive committee - which is chaired by the appointed district chief executive. The presiding member of the district assembly and the local MP(s) are not members. Crawford also points out that while this may be seen as furthering the principle of separation of powers at the local level, the effect is to vest power in an appointed representative of the central government to the detriment of elected leaders. On this point, Ayee (2000) is of the view that, both practically and legally, the presiding member and the MP do not represent any effective counterbalance to the dominance of the district chief executives. 
The dominant influence of central government over local legislatures is further amplified by Section 6 , sub-section 3 of the Local Governance Act 2016. This provision requires the president to appoint an interim management committee to oversee the functions of MMDAs whenever the Electoral Commission is unable to conduct district-level elections. Given that the Electoral Commission had to indefinitely postpone district-level elections in 2014 solely because of funding constraints, there is no guarantee that such scenarios may not be repeated in the future, and could serve as a convenient mechanism for the centre to usurp the powers of local governments. It would even be possible, in a 'worst case' scenario, for the centre to artificially create such a need.

\section{Are local bosses capable of challenging the authority of the centre?}

Turning to the fourth variable in Hutchcroft's (2001) analytical framework, in Ghana a number of constitutional provisions make it impossible for local bosses to challenge the authority of the centre. In terms of the theoretical powers and functions of the district assemblies - and for that matter the district chief executives - Section 12, sub-section 1(c) of the 2016 Act requires the district assembly to "provide guidance, give direction to and supervise other administrative authorities in the district as may be prescribed by law". Similarly, Section 21, sub-section 1(e) requires the executive committee to "make recommendations on stated grounds to the appropriate Ministry, Department or Agency, for the appointment and replacement of officers for departments outside the control of the District Assembly where it is considered expedient to do so". These wide-ranging powers are further affirmed by Section 20, sub-section 2(c), which states that the district chief executive shall "be responsible for the supervision of the departments of the Assembly".

While power is concentrated in the district chief executives, the president has the power to override them, cause their removal from office or use other discretionary powers to render them powerless; implying a reconcentration of powers in the presidency. Also there are constitutional provisions that make it possible for the president to recapture or usurp these powers. Section 36 of the 2016 Act gives the president the power to cause the performance of any function of a district assembly to be investigated. Section 37, sub-section 1 goes further, stating:

The President may declare a District Assembly to be in default of its functions by Executive Instrument if it is in the public interest to do so and may by the same or another Executive Instrument a) direct the District Assembly on how to perform any of its functions within the time specified in the Executive Instrument; or b) transfer to a person or body the performance of any of the functions of the District Assembly in default specified in the Executive Instrument.

In a similarly arbitrary fashion Section 37, sub-section 2 states that: "the President may by the same or another instrument, dissolve or suspend the District Assembly for not more than one year or prohibit that District Assembly from the performance of certain functions specified in the Executive Instrument for not more than one year. " Interestingly, the powers bestowed on the president can be invoked at any time without any consultations whatsoever. This could result in the usurpation of the functions of district 
assemblies by an over-zealous president for personal or political interests, particularly in a politically charged environment like Ghana.

Nor is it only political power that has been concentrated at the centre. Development planning has also been centralised, and MMDAs can only plan based on the whims of central governmental bodies. Section 86, sub-section 1 of the 2016 Act states that "the [National Development Planning] Commission shall prescribe the format of district development plans". Sub-section 2 stipulates that "each proposed District Development Plan shall be submitted through the Regional Co-ordinating Council to the Commission for consideration". The question then arises: who should be responsible for the approval of locally prepared development plans - district assemblies or central governmental bodies? In the Ghanaian system, although the 'in principle' answer is 'district assemblies', in practice this constitutional provision renders those powers toothless, transferring them instead to the NDPC.

Even more fundamental than the centralisation of political decision-making powers and development planning functions is the issue of autonomy over local law-making. Local-level legislation can have the force of law only if approved by the minister(s) - who acts on behalf of the president at the centre. Section 182, sub-sections 1-3 require district assemblies to submit their by-laws to their RCC for consideration and approval or rejection. However, as earlier indicated, the RCCs are headed by regional ministers, who are appointed by the president. Legislation approved therefore tends to reconcentrate district assemblies' powers in either the president or his assignees, agents and actors. This situation weakens the authority of local governments and reduces them to implementers of central government directives and administrative fiats.

\section{To what extent is decision-making authority concentrated in the executive?}

Leaving aside the question of centre-periphery relations, decision-making at the central government level does not in any way support Ghana's drive to decentralise. Instead, Ghana runs a quasi-executive system of government and, although the legislature and the judiciary are presumed to be independent, serving as checks on the executive, in practice several legislative, political and administrative structures combine to ensure that the executive remains a dominant force in decision-making processes. Simply put, decision-making authority at the capital is concentrated in the executive arm of government.

Constitutionally, the president is vested with wide-ranging powers and is therefore able to run government business however he/she deems fit. Wereko-Brobbey (2013) went so far as to refer to the powers of the president, as guaranteed by the 1992 Constitution of Ghana as constitutional dictatorship. It is certainly the case that Article 58 (1) states that "the executive authority of Ghana shall vest in the President and shall be exercised in accordance with the provisions of this Constitution", and that Article 58 (2) cements the sweeping nature of those powers when it states that "the executive authority of Ghana shall extend to the execution and maintenance of this Constitution and all laws made under 
or continued in force by this Constitution". The presidential powers are further reinforced by Article 58 (4), which states that "except as otherwise provided in this Constitution or by a law not inconsistent with this Constitution, all executive acts of Government shall be expressed to be taken in the name of the President". Judging by these legal provisions, Ghana as a country exists at the behest of the president, who has been granted unfettered powers by the laws of the land.

In most presidential systems, parliament and the judiciary serve as checks on the powers of the president. This is not the case in the Ghanaian system. Article 108 of the Constitution unambiguously states that:

Parliament shall not, unless the bill is introduced or the motion is introduced by, or on behalf of, the President - (a) proceed upon a bill including an amendment to a bill, that, in the opinion of the person presiding, makes provision for any of the following - (i) the imposition of taxation or the alteration of taxation otherwise than by reduction; or (ii) the imposition of a charge on the Consolidated Fund or other public funds of Ghana or the alteration of any such charge otherwise than by reduction; or (iii) the payment, issue or withdrawal from the Consolidated Fund or other public funds of Ghana of any moneys not charged on the Consolidated Fund or any increase in the amount of that payment, issue or withdrawal.

Thus - bizarrely - it is impossible even for the people's representatives, MPs, to have a voice in matters as critical as the imposition of taxes and the utilisation of funds accruing to the state.

It is clear that these legal texts make the executive arm the fulcrum of central government decisionmaking. Certain legally-specified general administrative practices also contribute in no small way to fortifying executive power and influence. The president appoints all of the following: over $50 \%$ of cabinet ministers; the speaker of parliament; the chief justice and other justices of the superior courts; the commissioner for human rights and administrative justice; and a multiplicity of other roles engaged in national decision-making. It is true that it is impossible for the president to sack most of the people so appointed, as he/she is mandated to only do so in consultation with various stakeholders; nevertheless, it is reasonable to suggest that, once appointed to a position, individuals are expected to show support and/or loyalty to the appointing authority.

\section{To what extent are local actors able to influence bureaucracies?}

Finally, turning to the last variable in Hutchcroft's (2001) framework, within Ghana the recruitment, placement and transfer of civil and local government staff has been entirely centralised, with the Office of the Head of Civil Service responsible for the recruitment, placement and transfer of civil servants, and the local government service responsible for staff within its secretariat. This practice effectively takes away from local authorities the power to control any persons in the service of local governance. It also contradicts constitutional provisions such as Article 240 (2)(d), and Article 37, sub-sections (1) and (2), which require the establishment of functional local governments, and mandates local authorities to "have such staff as may be necessary for the proper and efficient performance of its functions". 
Ayee (2008) has observed that the centralised nature of appointment, transfer and sanctioning of local government staff results in a situation of persistent allegiance of civil and local government staff to the centre. It also results in lack of control by local authorities over the tenure of officers working within their jurisdiction. He further reports instances where local authorities are deprived of key staff such as coordinating directors, finance officers and planning officers, among others, due to transfers dictated by central government agencies.

There is no doubt that current practice with regard to the recruitment, placement and transfer of local government staff does not give local authorities the discretion and authority they need to take action against non-performing officials. Local authorities are also rendered incapable of rationalising their staff to reflect their functions, geography, clients, administrative and technological needs.

\section{Conclusion}

This paper has examined the legislative, administrative and practical realities underpinning decentralisation in Ghana. It has established, using Hutchcroft's (2001) analytical framework, that practices at the local level are anything but decentralisation. While Ghana has solid principles for the decentralisation of government in a participatory manner, there exist significant deficits in implementation. On-the ground practices - legislative, administrative and political - indicate that the local government system in Ghana is controlled by forces at the centre. Local government officials, participatory processes, local legislatures and power structures have been so organised that the centre retains a dominant influence. Important functions such as development planning and making and approving by-laws have been recentralised through laws that require ministry or central government actor's sign-off before local measures can come into force.

The legislative and administrative structures of Ghana do not support the evolution of a genuine local government system - because legislative provisions stifle the emergence of a progressive local governance system, and administrative practices are manipulated by central government actors for partisan political goals. Although the Local Governance Act 2016 is touted as offering local governance in accordance with the Constitution of Ghana, (by establishing a local government service and a national system for development planning; by defining and regulating district assembly planning procedures; and by coordinating, facilitating, monitoring and supervising district assembly internal audit activities), it is significantly challenged and limiting. The 2016 Act is a mere reorganisation of its predecessor, the 1993 Act. Substantial portions of the earlier Act have been reproduced verbatim, and it remains to be seen whether progress towards genuine devolution can be achieved. Finally, the unitary political structures in Ghana also make it difficult for districts to function effectively on their own, given the paucity of resources and support infrastructure in the regions. 


\section{Declaration of conflicting interest}

The author declared no potential conflicts of interest with respect to the research, authorship, and/or publication of this article.

\section{Funding}

The author received no financial support for the research, authorship, and/or publication of this article.

\section{References}

African Peer Review Mechanism. (2005) Country review report and programme of action for the Republic of Ghana. Midrand, South Africa: APRM Secretariat.

Afrobarometer. (2008) Popular opinions on local government in Ghana, 2008. Afrobarometer Briefing Paper No. 52. Available at:

http://afrobarometer.org/sites/default/files/publications/Briefing\%20paper/AfrobriefNo52.pdf [Accessed 16 January 2018].

Agomor, K.S. and Obayashi, M. (2008) Potential and limitation of local radio in information accessibility in Ghana. In: Saito, F. (ed) Foundations for local governance: Decentralization in comparative perspective (pp. 259-276). Heidelberg: Physica-Verlag. https://doi.org/10.1007/978-3-7908-2006-5_12

Ahwoi, K. (2010) Local government \& decentralisation in Ghana. Accra: Unimax Macmillan.

Ayee, J.R.A. (2000) Decentralization and good governance in Ghana. Unpublished paper of May 2000 prepared for the Canadian High Commission, Accra, Ghana.

Ayee, J.R.A. (2008) The balance sheet of decentralisation in Ghana. In: Saito, F. (ed.) Foundations for local governance: Decentralisation in comparative perspective (pp. 233-258). Heidelberg: Physica-Verlag. https://doi.org/10.1007/978-3-7908-2006-5_11

Besley, T. and Coate, S. (2003) Centralied versus decentralized provision of public goods: A political economy approach. Journal of Public Economics, 87, 2611-2637. https://doi.org/10.1016/S0047-2727(02)00141$\mathrm{X}$

Boamah, N.A., Gyimah, C. and Nelson, J.K.B. (2012) Challenges to the enforcement of development controls in the Wa municipality. Habitat International, 36 (1), 136-142. https://doi.org/10.1016/j.habitatint.2011.06.010

Boex, J. and Yilmaz, S. (2010) An analytical framework for assessing decentralized local governance and local public sector. IDG Working Paper No. 2010-06. Washington, DC: The Urban Institute Centre on International Development and Governance.

Chireh, J.Y. (2009) Improving local government: The Commonwealth vision. Available at: http://slideplayer.com/slide/6880095/ [Accessed 5 June 2018].

Cobbinah, P.B. and Korah, P.I. (2016) Religion gnaws urban planning: The geography of places of worship in Kumasi, Ghana. International Journal of Urban Sustainable Development, 8 (2), 93-109. https://doi.org/10.1080/19463138.2015.1074581

Crawford, G. (2004) Democratic decentralisation in Ghana: Issues and prospects. POLIS Working Paper No. 9, prepared for Norwegian Association for Development Research (NFU), Annual Conference, Oslo

Diamond, L. (1999) Developing democracy: Toward consolidation: Baltimore: JHU Press.

Dick-Sagoe, C. (2012) Survey of literature of fiscal decentralization as a sustainable local development tool in Ghana. Journal of Sustainable Development in Africa, 14 (3), 228-251.

Eaton, K., Kaiser, K. and Smoke, P. (2011) The political economy of decentralisation reforms: Implications for aid. Washington, DC: The World Bank. https://doi.org/10.1596/978-0-8213-8840-2

European Commission. (2007) Supporting decentralisation and local governance in third countries: Tools and methods series. Luxembourg: European Commission. 
Ewool, G. (2003) The role of district assemblies in strengthening links of accountability. Available at: http://siteresources.worldbank.org/GHANAEXTN/Resources/role_dis_assemblies.pdf [Accessed 8 November 2017].

Ferrazzi, G. (2006) Ghana Local Government Act, 1993: A comparative analysis in the context of the review of the Act. Accra, Ghana: Ministry of Local Government, Rural Development and Environment/Deutsche Gesellschaft Für Technische Zusammenarbeit (GTZ).

Gennaioli, N. and Rainer, I. (2007) The modern impact of precolonial centralization in Africa. Journal of Economic Growth, 12, 185-234. https://doi.org/10.1007/s10887-007-9017-z

Goel, R.P. (2010) Other country decentralization experiences: Ghana. National Council of Applied Economics Research.

Government of Ghana. (2012) White Paper on the Report of the Constitution Review Commission of Inquiry. Available at: http://ghana.gov.gh/images/documents/crc_report_white_paper.pdf [Accessed 10 January 2018].

Government of Ghana. (2016) Local Governance Act 2016, Act 936. Tema: Ghana Publishing Corporation.

Hutchcroft, P. (2001) Centralisation and decentralisation in administration and politics: Assessing territorial dimensions of authority and power. Governance: An International Journal of Policy and Administration, 14 (1), 23-53. https://doi.org/10.1111/0952-1895.00150

Institute of Local Government Studies and Friedrich Ebert Stiftung. (2010) A guide to district assemblies in Ghana. Accra: Friedrich-Ebert-Stiftung Ghana.

Lambright, G.M. (2011) Decentralization in Uganda: Explaining successes and failures in local governance. Boulder, Colorado: First Forum Press.

Mann, M. (1993) The sources of social power, Vol. II. Cambridge: Cambridge University Press. https://doi.org/10.1017/CBO9780511570902

Manor, J. (1999) The political economy of democratic decentralisation. Directions in development. Washington, DC: The World Bank. https://doi.org/10.1596/0-8213-4470-6

McLaverty, P. (2017) Public participation and innovations in community governance. London and New York: Taylor \& Francis. https://doi.org/10.4324/9781315245652

Nunbogu, A.M. (2014) Self-organisation in informal settlements: A case study of the Greater Accra Metropolitan Area, Ghana. MSc Thesis, University of Groningen. Available at: http://scripties.frw.eldoc.ub.rug.nl/root/ma/EIP/2014/amnunbogu/.

Ouedraogo, H.M. (2003) Decentralisation and local governance: Experiences from Francophone West Africa. Public Administration and Development, 23 (1), 97-103. https://doi.org/10.1002/pad.263

Republic of Ghana. (1992) Constitution of the Republic of Ghana. Accra: Ghana Publishing Corporation.

Ribot, J. (2001) Local actors, powers and accountability in African decentralizations: A review of issues. Available at: https://www.odi.org/sites/odi.org.uk/files/odi-assets/events-documents/3187.pdf [Accessed 15 January 2018].

Scott, J.C. (1998) Seeing like a state: How certain schemes to improve the human condition have failed. New Haven and London: Yale University Press.

Wereko-Brobbey, C. (2013) The President takes all. Available at: http://www.peacefmonline.com/pages/comment/features/201308/171271.php?storyid=100\& [Accessed 13 July 2016]

Wunsch, J.S. (2001) Decentralization, local governance and 'recentralization' in Africa. Public Administration and Development, 21 (4), 277-288. https://doi.org/10.1002/pad.185

Wunsch, J.S. and Olowu, D. (1990) The failure of the centralized state: Institutions and self-governance in Africa. Bouolder, Colo.: Westview Press. 